\title{
Hubungan Antara Komitmen Organisasi dan Perilaku Kewargaan Organisasi pada Fungsionaris Partai Golkar di Bali
}

\author{
Dewa Ayu Diah Tri Paramita Putri Nida dan Nicholas Simarmata \\ Program Studi Psikologi, Fakultas Kedokteran, Universitas Udayana \\ Dewayu_tppn@yahoo.com
}

\begin{abstract}
Abstrak
Fenomena "kutu loncat" elit politik menjelang pemilihan umum berpengaruh terhadap instabilitas partai. Fenomena ini terkait dengan rendahnya komitmen organisasi dan perilaku kewargaan organisasi pada fungsionaris partai. Dengan berkomitmen pada organisasi, fungsionaris partai dapat mengidentifikasi diri terhadap tugas dan tujuan serta loyal terhadap organisasi. Hal ini kemudian membuat fungsionaris tersebut dapat memunculkan perilaku kewargaan organisasi. Penelitian ini bertujuan untuk mengetahui hubungan antara komitmen organisasi perilaku kewargaan organisasi pada fungsionaris Partai Golkar di Bali.

Penelitian ini adalah penelitian kuantitatif korelasional. Subjek penelitian ini adalah fungsionaris partai Golkar di Bali sebanyak 97 orang dengan kriteria masa bergabung minimal 5 tahun, berusia antara 25-65 tahun dan pendidikan minimal SMA/sederajat. Metode pengambilan sampelnya dengan metode convenience. Metode pengambilan datanya dengan Skala Komitmen Organisasi yang reliabilitasnya 0,814 dan Skala perilaku kewargaan organisasi yang reliabilitasnya 0,791 . Normalitas variabel komitmen organisasi sebesar 1,127 dan variabel perilaku kewargaan organisasi sebesar 0,878. Linieritas variabel komitmen organisasi dan variabel perilaku kewargaan organisasi sebesar 0,000. Metode analisis datanya dengan teknik korelasi product moment dari Pearson. Hasilnya menunjukkan bahwa ada hubungan positif yang signifikan antara komitmen organisasi dengan perilaku kewargaan organisasi dengan nilai korelasi 0,529 dan nilai probabilitas 0.000. Artinya ada hubungan antara komitmen organisasi dan perilaku kewargaan organisasi pada fungsionaris partai Golkar di Bali.
\end{abstract}

Kata kunci : Komitmen Organisasi, Perilaku Kewargaan Organisasi, Fungsionaris Partai Golkar

\begin{abstract}
A phenomenon called "Job Hopping" political elites facing the elections affects the instability of the party. This phenomenon is related to the lack of organization commitment and organizational citizenship behavior at the party functionaries. By committing to the organization, the party functionaries are able to identify themselves to the task and purpose and loyal to the organization. It then makes functionaries to demonstrate Organizational Citizenship behavior.

This study is aimed at determining the relationship between organizational commitment and Organizational Citizenship Behavior at Golkar Party functionaries. This research is a quantitative correlation. The subjects are Golkar party functionaries in Bali by 97 people with age criteria to join at least 5 years, between the ages of 25-65 years and a minimum of High School education/ equivalent. Method of collecting samples is the convenience method. Methods of collecting data are the Organizational Commitment Scale with its reliability 0.814 and Organizational Citizenship Behavior Scale with its reliability 0.791. Normality of commitment organizational variable is 1.127 and Organizational Citizenship Behavior variable is 0.878 . Linearity of organizational commitment variable and Organizational Citizenship Behavior variable are 0.000. Data analysis method is by using techniques of the Pearson product moment correlation. The result shows that there is a significant positive relationship between organizational commitment and Organizational Citizenship Behavior on Golkar party functionaries in Bali with 0.529 correlation values and probability value 0.000 .
\end{abstract}

Keywords: Organizational Commitment, Organizational Citizenship Behavior, Golkar Party Functionaries 


\section{LATAR BELAKANG}

Pasca kemerdekan Indonesia di tahun 1945, Indonesia sebagai sebuah bangsa yang merdeka telah mengalami perubahan dinamika sosial politik yang sangat panjang. Dinamika ini ditunjukkan pada perubahan sistem partai di Indonesia yang berdampak pada perubahan jumlah partai politik pada setiap pemilihan umum. Partai politik adalah kelompok yang anggota-anggotanya mempunyai orientasi, nilai-nilai, cita-cita yang terorganisir serta mengikuti pemilihan umum dan melalui pemilihan ini menempatkan calon-calonnya dalam tatanan jabatan publik (Budiarjo, 2008). Perubahan sistem partai politik membuat banyaknya partai baru yang bermunculan atau gugurnya partai karena tidak memenuhi syarat dalam verifikasi partai politik. Hal ini lalu berdampak pada kondisi adanya perpindahan fungsionaris dari satu partai ke pada partai lain. Proses berpindah dari satu partai ke partai lain disebut juga sebagai sebuah fenomena "kutu loncat" di kalangan fungsionaris partai (Detiknews, 2012).

Perpindahan fungsionaris partai sering terjadi karena adanya konflik internal partai, tawaran bergabung dari partai lain serta ketidakpuasan terhadap partai. Rasa tidak puas terhadap kondisi partai bahkan dapat memicu fungsionaris partai yang potensial membentuk partai baru karena kegagalan memperoleh kursi utama di partai sebelumnya (Gatra, 2012). Dalam tata sistem hukum di Indonesia tidak terdapat Undangundang yang mengatur dan melarang perpindahan antar anggota partai. Tidak adanya aturan ini membuat perpindahan antar partai menjadi mudah terjadi (Tempo, 2012). Hal ini akan berpengaruh terhadap kondisi organisasi partai itu sendiri. Kondisi adanya anggota partai yang berpindah berpengaruh terhadap instabilitas dari partai politik yang bersangkutan.

Perpindahan kader yang terjadi dalam tubuh internal partai akan membuat partai kehilangan dukungan suara yang menjadi pemilih dari kader yang berpindah serta diperlukan adanya adaptasi berupa penyesuaian terhadap struktur fungsionaris pada partai karena hilangnya fungsionaris pada posisi tertentu dan perlu adanya waktu dalam mengisi jabatan tersebut. Selain itu, faktor rusaknya pembentukan pola kaderisasi juga menjadi efek negatif dari banyaknya kader yang berpindah partai. Kerugian bagi adanya perpindahan tidak saja dialami oleh partai tapi juga oleh individu yang melakukan terkait dengan integritas dan kesetiaan fungsionaris terhadap partai di mata masyarakat (Ahmad, 2011).

Dampak negatif yang terjadi dengan adanya perpindahan fungsionaris partai ini membuat penting bagi sebuah partai politik untuk dapat mempertahankan anggota organisasi tetap berada di dalam partai. Fenomena perpindahan fungsionaris partai politik dalam ilmu psikologi industri dan organisasi dikaitkan dengan kondisi rendahnya komitmen fungsionaris pada organisasi. Fungsionaris partai adalah anggota partai yang difungsikan oleh partai pada jabatan politik sehingga setiap keputusan yang dibuat akan berpengaruh terhadap kondisi partai. Hal ini yang membuat perpindahan dari fungsionaris akan berdampak terhadap partai itu sendiri.

Berdasarkan paparan diatas maka komitmen organisasi dipandang sebagai hal yang penting dari fungsionaris partai terhadap keberlangsungan dari partai dan relevan terkait dengan perpindahan fungsionaris tersebut. Komitmen organisasi mencakup suatu perasaan dalam keterlibatan pekerjaan, kesetiaan, dan kepercayaan terhadap nilai-nilai organisasi. Untuk itu, organisasi memiliki peranan penting dalam meningkatkan komitmen individual, yaitu dengan memastikan para individual termotivasi dan puas dengan pekerjaan mereka (Aamodt, 2010). Komitmen organisasi akan membuat fungsionaris merasa menjadi bagian dan teridentifikasi pada partai sehingga fungsionaris partai akan percaya pada nilai dan tujuan dari organisasi. Hal ini tentu akan membawa fungsionaris partai ini dapat bekerja sejalan dengan partai sehingga tujuan dari partai akan dapat dicapai. Komitmen organisasi pada fungsionaris juga akan membuat fungsionaris memiliki loyalitas pada partainya. Greenberg \& Baron (2000) menyatakan bahwa anggota organisasi yang berkomitmen tinggi terhadap organisasi akan memiliki loyalitas yang tinggi pada organisasi.

Komitmen dalam organisasi menurut Allen dan Meyer (1991) terdiri atas tiga dimensi yaitu: Affective commitment didefinisikan sebagai seorang individu yang memiliki ikatan secara emosional dan teridentifikasi pada organisasi serta adanya perasaan terikat dan sepakat pada tujuan organisasi, continuance commitment merujuk pada adanya kesadaran akan biaya yang dikeluarkan ketika karyawan meninggalkan organisasi. Hal ini merupakan keadaan dimana karyawan merasa butuh untuk tetap berada di dalam organisasi karena meninggalkan perusahaan akan sangat merugikan bagi mereka, dan normative commitment adalah perasaan dari karyawan tentang kewajiban untuk tetap tinggal di dalam organisasi. Hal ini dipengaruhi oleh orangorang yang ada di sekitar karyawan seperti atasan dan rekan kerja.

Komitmen organisasi sebagai sebuah aspek penting dalam organisasi harus mendapat perhatian dari manajemen. Dessler (dalam Luthans, 2006) mengemukakan teori yang dapat membantu meningkatkan Komitmen Organisasi pada anggota organisasi antara lain, membuat aturan tertulis terkait organisasi, membangun komunikasi, menggunakan sistem rekruitmen berdasarkan nilai organisasi, pelatihan, keadilan organisasi, rasa komunitas serta adanya dukungan terhadap perkembangan bagi anggota organisasi dengan adanya kebebasan aktualisasi diri, promosi, dan keamanan dalam organisasi. Teori lain yang memberikan paparan tentang cara meningkatkan komitmen organisasi adalah teori dari Sweeney \& McFarlin (2002) dimana dijelaskan bahwa terdapat 
beberapa hal yang dapat diikuti untuk meningkatkan komitmen pada anggota organisasi yaitu kesempatan menyampaikan pendapat, sosialisasi tujuan, nilai, dan aturan dari organisasi serta pembagian kerja dalam tim sehingga dapat membuat individu terikat pada orang-orang dalam tim. Komitmen organisasi juga akan membuat fungsionaris partai melakukan tugas tanpa paksaan serta berkomitmen terhadap tugas diluar tanggung jawabnya secara formal, hal ini menandakan bahwa fungsionaris tersebut telah menunjukkan perilaku kewargaan organisasi.

Perilaku kewargaan organisasi merupakan perilaku pilihan anggota organisasi yang bukan merupakan kewajiban kerja secara formal namun dapat mendukung berfungsinya organisasi secara efektif (Robbins, 2006). Perilaku kewargaan organisasi melibatkan usaha melebihi tanggung jawab dimana fungsionaris partai akan bekerja diluar standar minimal dari tugas yang menjadi beban dan persyaratan minimum dari pekerjaan sebagai bagian anggota dari organisasi. Schultz \& Schultz (2006) menyatakan perilaku kewargaan organisasi sebagai perilaku dimana setiap anggota organanisasi akan menghadirkan perilaku positif sehingga akan mempercepat penyelesaian konflik serta membangun iklim kerja positif di partai.

Perilaku kewargaan organisasi merupakan perilaku individu yang ekstra, yang tidak secara langsung atau eksplisit dapat dikenali dalam suatu sistem kerja yang formal dan yang secara keseluruhan mampu meningkatkan efektivitas fungsi organisasi (Organ, 1988).

Perilaku kewargaan organisasi juga didefinisikan sebagai bentuk perilaku sukarela yang melebihi tuntutan tugas yang berkontribusi terhadap kesuksesan organisasi (Podsakoff, Ahaerna, \& Mackenzie, 1997). Schultz (2006) menyatakan bahwa perilaku kewargaan organisasi melibatkan usaha ekstra dimana pegawai melakukan suatu tindakan diluar tanggung jawab dan persyaratan minimum dari pekerjaan sebagai bagian dari organisasi. Perilaku kewargaan organisasi merupakan perilaku pilihan anggota organisasi yang bukan merupakan kewajiban kerja secara formal namun dapat mendukung berfungsinya organisasi secara efektif (Robbins, 2006). Borman dan Motowidlo (1993) mengatakan bahwa Perilaku kewargaan organisasi dapat meningkakan kinerja organisasi (organizational performance) karena perilaku ini merupakan pelumas dari mesin organisasi dengan kata lain adanya perilaku ini maka interaksi sosial anggotanya menjadi lancar.

Perilaku kewargaaan organisasi muncul karena perasaan sebagai anggota organisasi dan merasa rasa puas apabila dapat melakukan suatu yang lebih kepada organisasi. Perasaan sebagai bagian anggota organisasi dan kepuasaan, akan terjadi jika anggota memiliki persepsi yang positif terhadap organisasi (Sloat, 1999).
Hal ini dijelaskan pula oleh Organ (1988) dimana perilaku kewargaan organisasi dianggap memberikan kontribusi terhadap kesejahteraan komunitasnya, transformasi sumberdaya, peningkatan inovasi dan daya adaptasi serta kinerja organisasi secara keseluruhan termasuk peningkatan efektivitas dan efisiensi pengerahan sumberdaya, waktu dan pemecahan masalah di antara unit-unit kerja dengan cara kolektif dan interdependensi. .Perilaku kewargaan organisasi terdiri atas lima dimensi yang pertama kali diajukan oleh Organ (1998). lima dimensi perilaku kewargaan organisasi yaitu : altruism adalah perilaku yang merupakan pilihan personal karyawan, yang berpengaruh untuk membantu orang lain dalam menyelesaikan masalah organisasi dimana karyawan tersebut bernaung, conscientiousness adalah perilaku yang merupakan pilihan personal karyawan, yang melebihi tuntutan peran minimal dari organisasi pada area kehadiran, kepatuhan terhadap aturan dan sistem yang berlaku, pemanfaatan waktu istirahat, dan lain sebagainya, sportmanship adalah kesediaan karyawan untuk mentolerir dan tidak mengeluhkan kondisi organisasi yang tidak sesuai dengan kondisi ideal yang diharapkan, courtesy adalah bagian perilaku yang merupakan pilihan personal individu, yang bertujuan untuk mencegah munculnya masalah-masalah pekerjaan yang terkait dengan rekan sekerja dan civic virtue merupakan bagian perilaku individu yang mengindikasikan tanggung jawabnya untuk melibatkan diri atau memperhatikan keberlangsungan perusahaan.

Perilaku kewargaan organisasi sebagai suatu perilaku yang bersifat sukarela dan tanpa adanya sistem reward secara langsung terbentuk dan muncul karena dipengaruhi oleh banyak faktor. Menurut Podaskoff, dkk (dalam Garay, 2006) perilaku kewargaan organisasi dipengaruhi oleh empat faktor antara lain, karakteristik tugas, karakteristik organisasi, karakteristik pribadi dan perilaku dari pemimpin. Faktor lain yang dianggap mempengaruhi perilaku kewargaan organisasi adalah kepribadian, keadilan organisasi, kepuasan kerja, komitmen terhadap organisasi serta dukungan dari tempat bekerja (Prihatsanti \& Dewi, 2010). Teori lain yang membahas tentang faktor yang mempengaruhi perilaku kewargaan organisasi dipaparkan oleh Dyne, Graham, dan Dienesch (1994) dimana, faktor yang memperngaruhi perilaku kewargaan organisasi adalah sikap kerja, cyinism, nilai-nilai di organisasi, karakteristik pekerjaan, jabatan bekerja dan lama bekerja (dalam Teresa \& Suyasa, 2008) Berdasarkan pemaparan diatas maka komitmen organisasi pada fungsionaris partai menjadi hal yang penting terkait dengan tugas dan keberadaan fungsionaris di partai. Komitmen organisasi pada fungsionaris juga berhubungan dengan perilaku kewargaan organisasi. Komitmen organisasi yang tinggi pada fungsionaris akan membuat fungsionaris tersebut memberikan kontribusi terbaik melalui performa kerja. Komitmen organisasi yang membuat fungsionaris partai 
memunculkan rasa memiliki dan identifkasi diri terhadap keberadaan organisasi akan membuat fungsionaris partai melakukan tugas melebihi tugas tanpa reward secara formal. Hal ini mengindikasikan bahwa identifikasi dan loyalitas fungsionaris sebagai komitmen organisasi akan membuat fungsionaris bertahan pada organisasi dan membuat fungsionaris menghadirkan perilaku kewargaan organisasi.

\section{METODE}

\section{Variabel dan Definisi Operasional}

Variabel bebas dalam penelitian ini adalah komitmen organisasi. Definisi operasional dari komitmen organisasi adalah keseluruhan perasaan, sikap dan identifikasi diri anggota organisasi terhadap hal-hal yang berkaitan dengan organisasi dan pekerjaan yang diukur menggunakan Skala Pengukuran komitmen organisasi yang disusun oleh penulis melalui aspek-aspek yang melibatkan komitmen afektif, komitmen normatif, dan komitmen continuance.

Variabel tergantung dalam penelitian ini adalah perilaku kewargaan organisasi. Variabel ini sering disebut juga sebagai variabel tidak bebas, variabel terkait, atau dependent variabel (Arikunto, 2002). Perilaku Kewargaan Organisasi secara operasional didefinisikan sebagai perilaku yang bersifat sukarela, merupakan tindakan yang mengedepankan kepentingan organisasi tanpa bentuk paksaan maupun perintah formal, dan tidak berkaitan langsung dengan sistem reward yang diukur menggunakan skala pengukuran perilaku kewargaan organisasi yang disusun oleh penulis melalui aspek-aspek yang melibatkan altruism, conscientiousnes, sportmanship, courtesy, civic virtue.

\section{Hipotesis}

Berdasarkan permasalahan, pembahasan teori, dan kerangka pemikiran, hipotesis yang diajukan dalam penelitian ini adalah sebagai berikut: Ho = Tidak ada hubungan antara komitmen organisasi dan perilaku kewargaan organisasi pada fungsionaris partai Golkar, $\mathrm{Ha}=$ Ada hubungan antara komitmen organisasi dan perilaku kewargaan organisasi pada fungsionaris partai Golkar

\section{Responden}

Responden dalam penelitian ini adalah fungsionaris partai Golkar di Provinsi Bali. Alasan pemilihan subjek di Provinsi Bali adalah karena partai Golkar di provinsi Bali pernah menjadi pemenang pemilu di Bali selama masa pemerintahan orde baru dan kini menjadi partai dengan perolehan suara kedua di Provinsi Bali (KPU, 2009). Dinamika keberadaan partai ini menjadi alasan dipilihnya partai Golkar di Provinsi Bali sebagai subjek penelitian yang terkait dengan komitmen organisasi dan perilaku kewargaan organisasi.

Pemilihan fungsionaris partai sebagai responden dalam penelitian terkait dengan fungsi penting fungsionaris partai dalam sebuah organisasi partai. Fungsionaris partai adalah mesin penggerak organisasi sehingga setiap keputusan diambil oleh fungsionaris partai akan berdampak langsung pada partai (Suparsa, 2012). Fungsionaris yang diteliti adalah fungsionaris yang berada pada tingkat fungsionaris provinsi serta bertugas dalam organisasi partai di DPD tingkat II dan fungsionaris nasional dimana bergerak dan bertugas di organisasi partai di DPD tingkat I. Responden dalam penelitian ini memiliki kriteria tertentu seperti usia 25-65 tahun pemilihan usia subjek penelitian menjadi kriteria terkait dengan produktivitas fungsionaris pada partai, usia 25-65 tahun adalah usia produktif dari fungsionaris yang akan berpengaruh terhadap kinerja fungsionaris pada partai. Kriteria lain adalah masa bergabung dengan partai minimal 5 tahun, lama waktu bergabung yang ditentukan berdasarkan pada variabel penelitian komitmen organisasi sehingga diharapkan mereka telah memahami dan menghayati pekerjaan serta lingkungan organisasi dimana fungsionaris berada. Kriteria terakhir adalah pendidikan minimal SMA, persyaratan minimal pendidikan menjadi salah satu kriteria agar subjek dapat memahami pernyataan dalam skala penelitian.

Pada penelitian ini teknik pengambilan sampel yang digunakan adalah salah satu non-probability sampling yaitu convenience sampling. Teknik ini mengambil sampel dari populasi atas dasar kemudahan bertemu dengan subjek dengan persyaratan subjek yang sesuai (Oei, 2005). Pada penelitian ini, populasi penelitian berjumlah 537 orang yang berasal dari 8 kabupaten dan 1 kota madya. Jumlah minimal sampel yang harus diambil agar penelitian ini dapat digeneralisasikan dihitung dengan menggunakan rumus dari Slovin. Dari perhitungan dengan rumus dari Slovin diperoleh jumlah minimal sampel dalam penelitian ini agar dapat digeneralisasikan adalah 62 orang. Dalam penelitian ini jumlah sampel yang diambil akan melebihi dari jumlah minimal pengambilan sampel dengan kategori yang sesuai ketentuan sebelumnya.

\section{Tempat Penelitian}

Penelitian ini dilaksanakan pada bulan November hingga Desember 2012 bertempat di DPD tingkat I dan DPD tingkat II Partai Golkar di Provinsi Bali yang tersebar di sembilan kabupaten dan kota. Peneliti menyebar 110 skala kepada 110 subjek namun jumlah skala yang kembali dan dapat dianalisis hanya 97 skala. 


\section{Alat Ukur}

Alat ukur yang digunakan dalam penelitian ini terdiri dari dua alat ukur yaitu alat ukur komitmen organisasi dan alat ukur perilaku kewargaan organisasi yang disusun oleh peneliti. Alat ukur komitmen organisasi disusun berdasarkan teori dari Allen \& Mayer ( 1991) yang terdiri dari komponen affective comittment, normative commitment dan continuance commitment. Melalui uji kesahihan item pada skala komitmen organisasi dengan jumlah subjek yang digunakan dalam uji coba alat ukur adalah 30 orang, sebanyak 18 item setelah dilakukan analisis item ternyata menunjukkan bahwa terdapat 7 item yang gugur. Koefisien korelasi bergerak dari 0,343 hingga 0,781 . Sehingga alat ukur komitmen organisasi pada penelitian ini berjumlah 11 item. Uji reliabilitas menggunakan koefisien alfa $(\alpha)$ pada skala komitmen organisasi menunjukkan angka 0,814. Alfa $(\alpha)$ sebesar 0,814 ini dapat menunjukkan bahwa skala ini mampu mencerminkan 81,40\% variasi yang terjadi pada skor murni subjek yang bersangkutan sehingga dapat digunakan untuk mengukur atribut yang dimaksudkan, yaitu komitmen organisasi.

Alat ukur selanjutnya adalah alat ukur perilaku kewargaan organisasi, alatukur ini disusun berdasarkan teori dari Organ (1998) dimana akan terdiri dari Altruism, Conscientiousnes, Sportmanship, Courtesy, Civic Virtue. Dengan melalui uji kesahihan item skala perilaku kewargaan organisasi, maka terdapat 11 item yang gugur dari 30 item yang diuji dimana diperoleh koefisien korelasi yang bergerak dari 0,254 hingga 0,715. Sehingga untuk jumlah item yang sahih pada skala Perilaku Kewargaan Organisasi ada 19 item. Uji reliabilitas dengan menggunakan koefisien alfa $(\alpha)$ pada skala perilaku kewargaan organisasi menunjukkan angka 0,830 dengan jumlah subjek 30 orang dan jumlah item yang sahih ada 19 item. Alfa $(\alpha)$ sebesar 0,830 ini menunjukkan bahwa skala ini mampu mencerminkan 83,0 \% variasi yang terjadi pada skor murni subjek yang bersangkutan sehingga dapat digunakan untuk mengukur atribut yang dimaksudkan, yaitu perilaku kewargaan organisasi. Berdasarkan hasil koefisien korelasi tersebut, maka skala komitmen organisasi dan perilaku kewargaan organisasi mempunyai daya keterandalan yang tinggi.

Skala yang digunakan pada kuesioner komitmen organisasi dan skala perilaku kewargaan organisasi adalah skala likert dengan 5 (lima) kategori pilihan. Selain itu, alat ukur ini juga menggunakan skala likert karena setiap pilihan menunjukkan intensitas yang berbeda untuk membedakan peringkatnya. Kuesioner ini juga terdiri dari item favorable dan item unfavorable

\section{Metode Pengumpulan Data}

Data yang didapatkan oleh peneliti merupakan data primer dan data sekunder. Data sekunder dikumpulkan dengan cara mengambilan data yang telah ada di partai berupa arsip partai, buku dan surat-surat yang terkait dengan kebutuhan penelitian sedangkan metode pengumpulan data yang digunakan dalam pengambilan data primer pada penelitian ini adalah metode angket dengan alat pengumpulan datanya adalah skala pengukuran.

Skala yang digunakan dalam penelitian ini adalah skala Likert. Angket tersebut akan dibagikan kepada subjek selaku responden untuk diisi, sehingga akan menghasilkan atau memberikan respon jawaban tertulis terhadap sejumlah pernyataan yang telah disusun sebelumnya. Angket terdiri dari tiga bagian. Bagian pertama adalah identitas responden, bagian kedua adalah skala yang mengungkap komitmen organisasi dan bagian ketiga berupa skala untuk mengungkap perilaku kewargaan organisasi pada fungsionaris partai.

Metode pengumpulan data pada penelitian ini adalah melalui penyebaran kuesioner yang terdapat dari 2 alat ukur, dimana setiap alat ukur mewakili setiap variabel yaitu variabel komitmen organisasi dan perilaku kewargaan organisasi. Kedua alat ukur tersebut disusun berdasarkan konsep-konsep yang terdapat pada teori dan telah disesuaikan oleh peneliti sesuai dengan kondisi partai. Kuesioner ini diisi langsung oleh subjek penelitian pada hari dan jam yang telah disepakati oleh peneliti dengan pihak fungsionaris partai Golkar di Provinsi Bali.

\section{Teknik Analisis Data}

Analisis data yang digunakan dalam penelitian ini adalah dengan analisis statistik karena statistik bekerja dalam angka-angka, bersifat obyektif dan universal, dalam arti dapat digunakan hampir pada semua bidang penelitian. Teknik analisis statistik yang digunakan untuk dapat menguji hipotesis dalam penelitian ini adalah analisis korelasi pearson product moment yang dikemukakan oleh Karl Pearson. Sebelum menggunakan teknik analisis korelasi pearson product moment, maka data harus terlebih dahulu melewati uji asumsi data penelitian dengan melakukan uji normalitas dan linieritas.

Teknik analisis pearson product moment termasuk teknik statistik parametrik. Analisis ini digunakan karena merupakan analisis korelasional yang dapat dipakai untuk mengetahui derajat hubungan dan kontribusi variabel bebas dengan variabel terikat (Riduwan \& Sunarto, 2009). Sedangkan analisis yang digunakan untuk melihat dinamika dari aspek komitmen organisasi terhadap variabel perilaku kewargaan organisasi dianalisis menggunakan korelasi parsial. 


\section{HASIL PENELITIAN}

Untuk mengetahui tingkat komitmen organisasi dan perilaku kewargaan organisasi dari subjek penelitian maka dilakukan perbandingan antara rata-rata empiris dan rata-rata teoritis. Berikut ini disajikan tabel yang berisi rata-rata teoritis, rata-rata empiris dan standar deviasi (SD) hasil penelitiaan.

\begin{tabular}{cccc}
\multicolumn{5}{c}{ Tabel 1 } \\
Tabel Rata-nata Teoritis, Rata-rata Eupirik dan Standar Deviasi \\
\hline Skala & $\begin{array}{c}\text { Rata-rata } \\
\text { Teoritis }\end{array}$ & $\begin{array}{c}\text { Rata-rata } \\
\text { Euyinis }\end{array}$ & SD \\
\hline Komitumen Organisasi & 33 & 44,05 & 5.017 \\
$\begin{array}{c}\text { Perilaku Kewargann } \\
\text { Organisasi }\end{array}$ & 57 & 75,22 & 8.787 \\
\hline
\end{tabular}

Rata-rata teoritis adalah rata-rata skor penelitian. Rata-rata teoritis diperoleh dari angka yang menjadi titik tengah alat ukur penelitian. Rata-rata empiris adalah rata-rata skor data penelitian. Rata-rata empiris diperoleh dari angka yang merupakan rata-rata data penelitian. Dari data yang telah dianalisis untuk variabel komitmen organisasi didapatkan hasil rata-rata teoritis sebesar 33 yang lebih kecil daripada rata-rata empiris yang sebesar 44.05. Hal ini menunjukkan bahwa ratarata subjek dalam penelitian ini memiliki tingkat komitmen organisasi yang tinggi. Sedangkan pada variabel perilaku kewargaan organisasi diperoleh rata-rata teoritis sebesar 57 yang lebih kecil daripada rata-rata empiris yang sebesar 75,22. Hal ini menunjukkan bahwa rata-rata subjek dalam penelitian ini memiliki tingkat perilaku kewargaan organisasi yang tinggi.

Analisis data yang digunakan dalam penelitian ini adalah dengan menggunakan teknik korelasi product moment dari Karl Pearson. Tapi sebelum metode analisis tersebut dilakukan, terlebih dahulu diperlukan adanya syarat yang harus terpenuhi, yaitu dengan melakukan uji asumsi meliputi uji normalitas dan uji linearitas.

\begin{tabular}{|c|c|c|}
\hline & $\begin{array}{c}\text { Tabel } 2 \\
\text { Hasil Uji Normalitas }\end{array}$ & \\
\hline & Kounitmen Organisasi & $\begin{array}{c}\text { Perialan Kewargann } \\
\text { Orgnnisasi }\end{array}$ \\
\hline $\begin{array}{c}\text { Kolmogorov-Sunirnov Z } \\
\text { Aymy. Signifficant }\end{array}$ & $\begin{array}{l}1,127 \\
0,157\end{array}$ & $\begin{array}{l}0,878 \\
0,424 \\
\end{array}$ \\
\hline
\end{tabular}

Hasil uji normalitas pada variabel komitmen organisasi memiliki nilai signifikansi dengan probabilitas (p) 0,157 dan variabel perilaku kewargaan organisasi memiliki nilai signifikansi dengan probabilitas (p) 0,424 dimana mempunyai nilai di atas 0,05 ( $\mathrm{p}>0,05)$. Hal ini menunjukkan bahwa sebaran data pada variabel komitmen organisasi dan variabel perilaku kewargaan organisasi bersifat normal.

Tabel 3

Hasil Uji Linearitas

\begin{tabular}{|c|c|c|c|c|}
\hline & & & $F$ & Signifikansi \\
\hline $\mathrm{KO} \mathrm{PKO}^{+}$ & $\begin{array}{l}\text { Benween } \\
\text { Groups }\end{array}$ & $\begin{array}{c}\text { (Combined) } \\
\text { Linomity } \\
\text { Deviation from Linarity }\end{array}$ & $\begin{array}{c}2.834 \\
37.675 \\
1.092\end{array}$ & $\begin{array}{l}.001 \\
.000 \\
.376\end{array}$ \\
\hline
\end{tabular}

Hasil pengujian menunjukkan bahwa hubungan kedua variabel adalah linear karena memiliki probabilitas (p) sebesar 0,000 atau memiliki taraf signifikansi untuk linearitas lebih kecil dari $0,05(\mathrm{p}<0,05)$ sehingga dikatakan bahwa hubungan antara skor variabel komitmen organisasi dan perilaku kewargaan organisasi telah menunjukkan adanya garis yang sejajar atau lurus.

Pengolahan data untuk menguji hipotesis yang mengkorelasikan antara variabel komitmen organisasi dan variabel perilaku kewargaan organisasi menggunakan metode atau teknik analisis korelasi product moment dari Karl Pearson dilakukan secara komputasi melalui program SPSS versi 17, dengan taraf signifikansi 0,01 artinya bahwa kemungkinan penolakan hipotesis yang benar adalah 1 diantara 100. Dengan kata lain, kepercayaan terhadap kebenaran hipotesis adalah sebesar $99 \%$.

\begin{tabular}{|c|c|c|}
\hline \multicolumn{3}{|c|}{$\begin{array}{c}\text { Tabel } 4 . \\
\text { Hasil Uji Korelasi }\end{array}$} \\
\hline & & Total Komifmen Organisasi \\
\hline $\begin{array}{l}\text { Total } \\
\text { Perilhbu Kewargan } \\
\text { Organisasi }\end{array}$ & $\begin{array}{l}\text { Pearson Correiation } \\
\text { Sig (2-tailedi) } \\
\text { N }\end{array}$ & $\begin{array}{l}.529^{\prime \prime} \\
.000 \\
97\end{array}$ \\
\hline
\end{tabular}

Melalui hasil pengolahan data dengan program SPSS 17.0 tersebut diperoleh nilai koefisien korelasi (r) sebesar 0,529. Angka korelasi yang diperoleh sebesar (+) 0,529 menunjukkan adanya hubungan antara variabel komitmen organisasi dan variabel perilaku kewargaan organisasi. Sedangkan tanda positif (+) menunjukkan bahwa semakin tinggi komitmen organisasi maka akan mengakibatkan semakin tinggi pula perilaku kewargaan organisasi. Hal ini memiliki arti bahwa kedua variabel memiliki hubungan atau saling berkorelasi.

Koefisien determinasi (r2) diperoleh dengan mengkuadratkan nilai $\mathrm{r}(0,529)$ sehingga didapatkan hasil $\mathrm{r} 2$ sebesar 0,280. Koefisien determinasi menunjukkan besarnya peran atau sumbangan yang dapat diberikan oleh variabel bebas terhadap variabel tergantung. Dalam penelitian ini, sumbangan variabel komitmen organisasi terhadap variabel perilaku kewargaan organisasi 28\%. Sedangkan sumbangan selain dari variabel komitmen organisasi terhadap variabel perilaku kewargaan organisasi adalah sebesar $72 \%$, yang diperoleh dari faktor-faktor lainnya.

Tabel 5 .

Hasil Uji Hipotesis

\begin{tabular}{lll}
\hline & & Total Komitmen Organisasi \\
\hline Total & Pearson Correiation & $.529^{* 2}$ \\
Perihla Kewargan & Sig (2-tailed) & .000 \\
Organisasi & $\mathrm{N}$ & 97 \\
\hline
\end{tabular}

Dari korelasi variabel komitmen organisasi dan variabel perilaku kewargaan organisasi, diperoleh angka probabilitas (p) 0,000, dimana angka tersebut mencerminkan $p$ $<0,05$ yang berarti hipotesis nolnya ditolak dan hipotesis alternatifnya yang menyatakan bahwa ada hubungan positif 
antara komitmen organisasi dan perilaku kewargaan organisasi pada fungsionaris diterima.

Melalui hasil uji korelasi parsial dengan program SPSS 17.0 maka diperoleh hasil koefisen korelasi parsial antara dimensi dari variabel komitmen organisasi terhadap variabel perilaku kewargaan organisasi sebagai berikut :

$$
\text { Tabel } 6 .
$$

Tabel Korelasi Parsin]

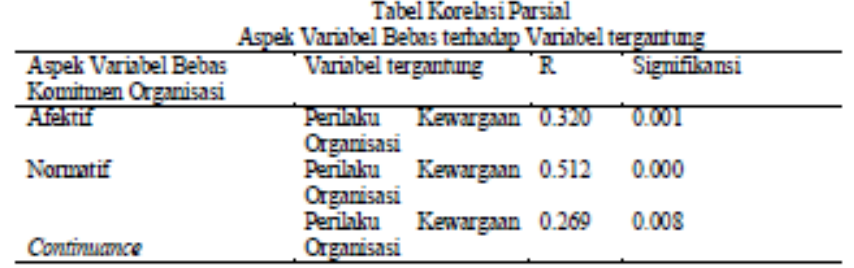

Nilai korelasi parsial dari dimensi komitmen normatif dengan perilaku kewargaan organisasi yaitu 0,512; dimensi komitmen afektif dengan perilaku kewargaan organisasi yaitu 0,320; dan komitmen continuance dengan perilaku kewargaan organisasi yaitu 0,269. Dari hasil koefisen korelasi parsial tersebut menunjukan bahwa dimensi komitmen normatif dengan perilaku kewargaan organisasi memiliki nilai koefisien korelasi parsial paling besar yang menunjukkan bahwa dimensi komitmen normatif memiliki hubungan paling kuat terhadap perilaku kewargaan organisasi. Dimensi selanjutnya yang memiliki hubungan terhadap perilaku kewargaan organisasi adalah dimensi komitmen afektif dengan koefisien korelasi 0,320. Nilai koefisien korelasi parsial 0,320 ini menunjukkan bahwa dimensi afektif memiliki hubungan yang menengah diantara ketiga dimensi komitmen organisasi dengan perilaku kewargaan organisasi dan hubungan paling lemah ditunjukan oleh komitmen continuance terhadap perilaku kewargaan organisasi dengan koefisien korelasi parsial 0,269.

Skala komitmen organisasi terdiri dari 11 item yang masing-masing itemnya memiliki skor 1, 2, 3, 4 dan 5. Dengan demikian, skala kecerdasan emosional memiliki skor terkecil atau minimal sebesar 11 (11 x 1), skor terbesar atau maksimal sebesar 55 (11 x 5) sehingga memiliki rentangan skor skala sebesar 44 (55-11). Pada skala ini diperoleh standar deviasi $(\sigma)$ sebesar $7,33(44: 6)$ dan rata-rata teoritis $(\mu)$ sebesar $33[(11+55): 2]$. Hasil penghitungan untuk skala komitmen organisasi dapat dilihat pada tabel berikut :

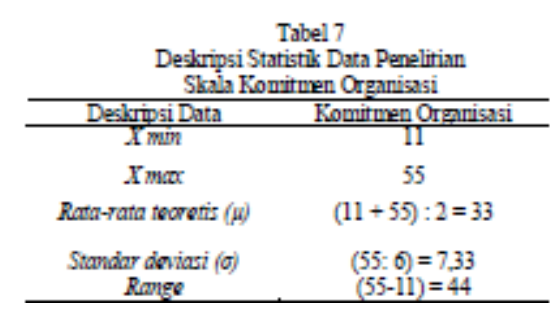

Kategorisasi skala komitmen organisasi dapat dilihat pada tabel berikut :

\begin{tabular}{|c|c|c|c|c|}
\hline \multicolumn{5}{|c|}{$\begin{array}{c}\text { Tabel } 8 \\
\text { Tabel Kategorisasi Subjek pada Skah Komitmen Oremnisasi }\end{array}$} \\
\hline Variabel & Rentang Nini & Kategori & Subjek & Persentase \\
\hline $\begin{array}{l}\text { Komifusen } \\
\text { Orgmisasi }\end{array}$ & $\begin{array}{c}\mathrm{X} \leq 22 \\
22 \leq \mathrm{X} \leq 29,33 \\
29,33 \leq \mathrm{X} \leq 36,66 \\
36,66 \leq \mathrm{X} \leq 43,99 \\
43,99<\mathrm{X} \\
\text { Jumlah }\end{array}$ & $\begin{array}{l}\text { Sangat Kendah } \\
\text { Rendah } \\
\text { Sedang } \\
\text { Tinggi } \\
\text { Sangat Tinggi }\end{array}$ & $\begin{array}{l}0 \text { orang } \\
0 \text { orang } \\
11 \text { orang } \\
26 \text { orang } \\
60 \text { orang } \\
97 \text { orang }\end{array}$ & $\begin{array}{l}0 \% \\
0 \% \\
11,3 \% \\
26,8 \% \\
61,8 \% \\
100 \%\end{array}$ \\
\hline
\end{tabular}

Analisis kategorisasi pada skala komitmen organisasi menunjukkan bahwa subjek yang termasuk dalam kategori sangat tinggi ada $61,8 \%$ kategori tinggi ada $26,8 \%$ dan kategori sedang ada $11,3 \%$ sedangkan pada kategori rendah dan sangat rendah tidak terdapat subjek atau $0 \%$. Melalui tabel diatas, dapat dilihat bahwa terdapat 60 orang yang masuk ke dalam kategori sangat tinggi, 26 orang masuk dalam kategori tinggi dan 11 orang masuk dalam ketegori sedang.

Banyaknya item yang disajikan pada skala perilaku kewargaan organisasi berjumlah 19 item yang masing-masing item memiliki skor 1, 2, 3, 4 dan 5. Dengan demikian, skala perilaku kewargaan organisasi memiliki skor terkecil atau minimal sebesar 19 (19 x 1), skor terbesar atau maksimal sebesar 95 (19 x 5) sehingga skala ini memiliki rentangan skor sebesar 76 (95-19). Pada skala ini diperoleh standar deviasi $(\sigma)$ sebesar 12,6 (76:6) dan rata-rata teoritis $(\mu)$ sebesar 57 [(19+95): 2]. Hasil penghitungan untuk skala perilaku kewargaan organisasi dapat dilihat pada tabel berikut

$$
\text { Tabel } 9
$$

Deskripsi Statistik Data Penelitian

\begin{tabular}{ll}
\multicolumn{2}{c}{ Skala Perilaku Kewargann Organisasi } \\
\hline Deskripsi Data & $\begin{array}{l}\text { Perilaku } \\
\text { Organisasi }\end{array}$ \\
\hline$X$ min & 19 \\
$X$ wax & 95 \\
Rata-rata tooretis $(\mu)$ & $(19+95): 2=57$ \\
Standar Doviasi $(\sigma)$ & $(76: 0)=12,66$ \\
Range & $(95-19)=76$ \\
\hline
\end{tabular}

Kategorisasi skala perilaku kewargaan organisasi

\begin{tabular}{|c|c|c|c|c|}
\hline & vel Kategorisasi Sy & $\begin{array}{c}\text { Tabel } 10 \\
\text { pada Skala Pe }\end{array}$ & In Ker & \\
\hline Variabel & Rentang Nilai & Kategori & Subjek & Persentase \\
\hline Penilak & $\mathrm{X} \leq 3801$ & Sangat Rench & Oorang & $0 \%$ \\
\hline Kewargan & $38,01 \leq \mathrm{X} \leq 50,67$ & Rendah & 0 orang & $0 \%$ \\
\hline Organisasi & $50,67 \leq \mathrm{X} \leq 63,33$ & Sedang & 13 orang & $13,4 \%$ \\
\hline & $63,33 \leq \mathrm{X} \leq 75,99$ & Tinggi & 24 orang & $24,74 \%$ \\
\hline & $75,99<\mathrm{X}$ & Sangat Tinggi & 60 orang & $61.8 \%$ \\
\hline Jumlah & & & 97 orang & $100 \%$ \\
\hline
\end{tabular}
dapat dilihat pada tabel berikut:

Analisis kategorisasi pada skala perilaku kewargaan organisasi menunjukkan bahwa subjek yang termasuk dalam kategori sangat tinggi ada $61,8 \%$, kategori tinggi ada $24,74 \%$ dan kategori sedang ada $13,4 \%$ dan tidak terdapat subjek yang masuk pada kategori kategori rendah dan sangat rendah. Melalui tabel diatas, dapat dilihat bahwa terdapat 60 orang 
masuk dalam kategori sangat tinggi, 24 orang masuk dalam kategori tinggi, dan 13 orang masuk dalam kategori sedang.

Profil Partai Golkar

Partai Golkar bermula pada tahun 1964 dengan berdirinya Sekretariat Bersama Golongan Karya (Sekber Golkar) di masa akhir pemerintahan Presiden Soekarno. Sekber Golkar didirikan oleh golongan militer khususnya perwira Angkatan Darat dengan menghimpun organisasi pemuda, wanita, sarjana, buruh, tani, dan nelayan pada tanggal 20 Oktober 1964. Sekber Golkar ini merupakan wadah dari golongan fungsional/golongan karya murni yang tidak berada dibawah pengaruh politik tertentu (Golkar, 2010).

Dalam proses pembentukan organisasi, Sekber Golkar di tingkat pusat mengintruksikan pembentukan Sekber Golkar di tingkat daerah maupun cabang sehingga dalam Mukernas Sekber Golkar di tahun 1965 dirumuskan dan diputuskan tentang penyusunan Sekber di tingkat daerah. Keputusan dalam Mukernas Sekber Golkar ini menjadi awal pembentukan Sekber Golkar di berbagai daerah termasuk di Provinsi Bali (Oka, 1993).

Sekber Golkar di Provinsi Bali dibentuk pada tanggal 28 Januari 1966, pembentukan di tingkat provinsi juga diikuti pembentukan Sekber Golkar di setiap Kabupaten di Provinsi Bali dengan urutan pembentukan dimulai dari Badung ( 31 Maret 1966), Tabanan ( 4 April 1966), Gianyar (5 April 1966), Klungkung (6 April 1966), Bangli (7 April 1966), Buleleng (11 April 1966), Karangasem (12 April 1966), dan Jembrana (13 April 1966). Sekber Golkar di Provinsi Bali dioptimalkan dengan pelaksanaan konsolidasi yang dilakukan dengan dukungan penuh dari golongan ABRI (Pendit, 1979). Anggota Sekber Golkar pada awalnya berjumlah 61 organisasi yang kemudian berkembang hingga mencapai 291 organisasi. Jumlah anggota Sekber Golkar ini bertambah dengan pesat, karena golongan fungsional lain yang menjadi anggota Sekber Golkar. Organisasi-organisasi yang terhimpun ke dalam Sekber Golkar ini kemudian dikelompokkan berdasarkan kekaryaannya ke dalam 7 (tujuh) Kelompok Induk Organisasi (KINO), yaitu Koperasi Serbaguna Gotong Royong (KOSGORO), Sentral Organisasi Karyawan Swadiri Indonesia (SOKSI), Musyawarah Kekeluargaan Gotong Royong (MKGR), Organisasi Profesi, Ormas Pertahanan Keamanan (HANKAM), Gerakan Karya Rakyat Indonesia (GAKARI) dan Gerakan Pembangunan Untuk menghadapi Pemilu 1971. Kelompok kekaryaan ini kemudian menjadi inti kekuatan dari Sekber Golkar dimana pada tanggal 4 Februari 1970 Sekber Golkar ikut menjadi peserta Pemilu melalui satu nama dan tanda gambar yaitu Golongan Karya (Golkar). Pada Pemilu 1971 Sekber Golkar sukses dan berhasil menang dengan 34.348.673 suara atau 62,79 \% dari total perolehan suara. Perolehan kemenangan suara hampir merata di seluruh propinsi, kemenangan Sekber Golkar juga terjadi di Sekber Golkar Bali.
Sesuai ketentuan dalam ketetapan MPRS mengenai perlunya penataan kembali kehidupan politik Indonesia, pada tanggal 17 Juli 1971 Sekber Golkar mengubah dirinya menjadi Golkar. Golkar menyatakan diri bukan partai politik karena terminologi partai politik mengandung pengertian dan pengutamaan politik dengan mengesampingkan pembangunan dan karya (Azwar, 2009). Kemunculan Golkar di Bali sempat diragukan akan mampu memperoleh dukungan suara mengingat kuatnya pengaruh PNI pada masa itu. Pengaruh dukungan dari Dwi fungsi ABRI disebut sebagai salah satu faktor utama kemenangan Golkar di Bali (Oka, 1993).

Selama puluhan tahun Orde Baru berkuasa, jabatanjabatan dalam struktur eksekutif, legislatif dan yudikatif, diduduki oleh kader-kader Golkar. Politik Orde Baru diciptakan dan kemudian dilaksanakan oleh pimpinan militer dan Golkar. Keluarga besar Golongan Karya sebagai jaringan konstituen, dibina sejak awal Orde Baru melalui suatu pengaturan informal yaitu jalur A untuk lingkungan militer, jalur B untuk lingkungan birokrasi dan jalur $G$ untuk lingkungan sipil di luar birokrasi (Nurvida, Ananta, \& Suryadinata, 2005). Pemuka ketiga jalur terebut melakukan fungsi pengendalian terhadap Golkar lewat dewan pembina yang mempunyai peran strategis. Jadi dalam setiap pemilu Golkar selalu tampil sebagai pemenang. Kemenangan Golkar diukir dalam pemilu di tahun 1977, 1982, 1987, 1992, dan 1997 (KPU, 2009). Kemenangan mutlak dalam setiap pemilu ini juga terjadi di Provinsi Bali. Golkar di Provinsi Bali menjadi bagian dari pemerintah yang mensukseskan program pemerintah melalui kampanye pembangunan berbasis pariwisata. Partai lain seperti PDI Perjuangan saat itu hanya mampu bertahan di beberapa daerah yang dikenal sebagai simpatisan PNI (Dwipayana, 2004).

Bergulirnya arus reformasi memunculkan adanya tuntutan mundur kepada Presiden Soeharto. Tuntutan mundur dan perubahan pemerintahan orde baru ini berdampak pada Golkar. Hal ini karena Golkar dianggap sebagai bagian dari Presiden Soeharto dan pemerintahan orde baru sehingga tuntutan pembubaran juga mengarah pada Golkar (Tanjung, 2007). Di bawah kepemimpinan Akbar Tanjung, Golkar berubah bentuk menjadi Partai Golkar dengan mengusung citra sebagai Golkar baru. Partai Golkar kemudian mengiikuti pemilu di tahun 1999 berkompetisi bersama partai-partai baru di era multipartai (Azwar, 2009).

Pada pemilu pertama di era reformasi pada tahun 1999 partai Golkar mengalami penurunan suara di peringkat ke dua di bawah PDIP. Kondisi ini tentu berimbas dengan perolehan suara partai Golkar di Bali. Suara yang diperoleh partai Golkar turun dan digantikan dengan peningkatan suara pada PDI Perjuangan. Sedangkan pada pemilu kedua tahun 2004 partai Golkar meraih kemenangan secara nasional dengan 24.480.757 suara atau $21,58 \%$ suara sah akan tetapi kemenangan secara nasional tidak berdampak pada posisi 
partai Golkar di Bali, posisi partai Golkar di Bali tetap sebagai partai dengan perolehan suara terbesar kedua dibawah PDI Perjuangan (KPU, 2009). Perubahan dukungan partai ini berdampak pada penurunan jumlah kursi wakil partai Golkar di legislatif serta kemenangan partai Golkar dalam pemilihan kepada daerah. Perolehan kemenangan dalam pemilihan kepala daerah hingga tahun 2013 partai Golkar hanya memiliki wakil di Kabupaten Karangasem dan Badung.

Struktur organisasi partai Golkar tersusun dari tingkat pusat, tingkat provinsi (DPD tingkat I), tingkat kabupaten/kota ( DPD tingkat II), pengurus Kecamatan (PK) hingga ke tingkat pengurus desa (Karakterdes). Pengurus partai Golkar Provinsi Bali terbagi di 8 Kabupaten dan 1 kota madya, fungsionaris yang bertugas di DPD Tingkat II disebut fungsionaris provinsi dengan konsentrasi pelaksanaan tugas di tingkat kabupaten sedangkan fungsionaris yang bertugas di DPD tingkat I disebut fungsionaris nasional dengan konsentrasi pelaksaan tugas di tingkat provinsi. Jumlah fungsionaris partai Golkar di Provinsi Bali yang duduk dalam kepengurusan di tingkat provinsi dan kabupaten berjumlah 537 orang. Fungsionaris pada tingkatan tersebut akan menjadi mesin penggerak utama partai yang bertugas mengaktifkan kader partai Golkar di bawah. (Suparsa, 2012).

Selain kepengurusan partai, partai Golkar juga memiliki organisasi sayap dimana organisasi ini akan dapat membantu pelaksaan program yang dapat menunjang tujuan dari partai. Organisasi sayap yang ada di partai Golkar antara lain organisasi sayap perempuan, yaitu Kesatuan Perempuan Partai Golongan Karya (KPPG) dan Organisasi sayap pemuda yaitu Angkatan Muda Partai Golongan Karya (AMPG) dan pembentukan organisasi sayap lain yang sesuai dengan kebutuhan dari partai. Partai Golkar adalah partai yang berasaskan Pancasila. Sistem pengaturan dan konsolidasi partai Golkar di Provinsi Bali mengikuti sistem yang ada di Partai Golkar tingkat pusat mengacu pada AD-ART (Golkar, 2010).

Selama 48 tahun berdiri dan menjalani proses politik, partai Golkar telah mengalami dinamika politik yang telah menempatkan partai pada dua posisi pencapaian politik yang jauh berbeda. Era kejayaan partai di masa orde baru dan terpuruknya partai di awal era reformasi. Proses perjalanan ini yang juga menghadirkan fenomena perpindahan dari kaderkader partai. Beberapa kader potensial yang berpindah atau membentuk partai baru. Setelah munculnya partai Hanura dan partai gerindra kini partai Golkar juga ditinggalkan oleh Surya Paloh dengan partai barunya yaitu Nasional Demokrat ( Nasdem). Kondisi tersebut juga terjadi pada partai Golkar di Provinsi Bali dengan adanya perpindahan dan pengunduran diri beberapa fungsionaris partai Golkar. Perpindahan fungsionaris di Partai Golkar merupakan sebuah proses dan kebebasan berpolitik bagi setiap individu (Suparsa, 2012). Di bawah kepemimpinan dari Aburizal Bakrie sebagai ketua umum partai dan Ketut Sudikerta sebagai ketua partai Golkar provinsi Bali partai Golkar Bali siap dan optimis menghadapi pemilu di tahun 2014 dengan memegang slogan “ Suara Rakyat Suara Golkar”.

\section{PEMBAHASAN DAN KESIMPULAN}

Hipotesis pada penelitian ini yang berbunyi ada hubungan antara komitmen organisasi dan perilaku kewargaan organisasi pada fungsionaris partai Golkar dapat diterima. Dapat diterimanya hipotesis tersebut karena dilihat dari hasil analisis statistik yang menggunakan teknik korelasi product moment dari Karl Pearson yaitu koefisien korelasi (r) antara variabel komitmen organisasi dan perilaku kewargaan organisasi adalah 0,529 dimana angka probabilitas yang didapat adalah sebesar $0,000(\mathrm{p}<0,05)$ yang berarti bahwa variabel komitmen organisasi dan variabel perilaku kewargaan organisasi saling berkorelasi secara signifikan dan positif. Hal ini berarti bila terjadi peningkatan pada variabel komitmen organisasi maka akan terjadi peningkatan juga pada variabel perilaku kewargaan organisasi.

Fungsionaris partai yang memiliki komitmen organisasi yang tinggi adalah fungsionaris yang memiliki sikap tertarik secara konsisten terhadap tujuan, nilai dan sasaran partai dimana fungsionaris tersebut bernaung. Komitmen organisasi pada fungsionaris partai ditunjukkan dengan penerimaan dan kepatuhan individu terhadap nilai dan tujuan organisasi sehingga individu akan mengidentifikasi keterlibatan dirinya terhadap suatu organisasi.

Komitmen organisasi ditandai juga dengan adanya kesiapan dan kesediaan untuk dapat berusaha dengan sungguh-sungguh karena organisasi dan keinginan untuk terus mempertahankan keanggotaan dalam organisasi. Hal ini menunjukkan bahwa fungsionaris memiliki rasa identifikasi (kepercayaan terhadap nilai-nilai organisasi), loyalitas (keinginan untuk tetap menjadi anggota organisasi yang bersangkutan) dan keterlibatan (kesediaan untuk berusaha sebaik mungkin demi kepentingan organisasi). Hal ini tentu akan mendukung fungsionaris untuk dapat menampilkan perilaku kewargaan organisasi yang tinggi pada organisasi. Sebaliknya, fungsionaris partai yang memiliki komitmen organisasi yang rendah akan cenderung sulit dalam menerima tujuan dan nilai organisasi, menghindari keterlibatan pada kegiatan partai, enggan menampilkan kontribusi terbaiknya terhadap partai serta mudah memiliki keinginan untuk berpindah atau keluar dari partai tempatnya bergabung. Hal ini tentu saja akan membuat fungsionaris tidak menampilkan perilaku kewargaan organisasi pada partai sebagai bentuk identifikasi, keterlibatan dan loyalitasnya terhadap partai.

Hasil penelitian ini didukung oleh hasil penelitian lain, yaitu Teresa dan Suyasa (2008) yang menyatakan bahwa komitmen organisasi merupakan salah satu faktor dalam meningkatkan intensitas dari perilaku kewargaan organisasi. 
Semakin anggota organisasi tersebut berkomitmen terhadap organisasinya maka hal tersebut akan membuat anggota organisasi melakukan tugas melebihi tanggung jawabnya. Pelaksaan tugas diluar tanggung jawab ini mengarah pada perilaku kewargaan organisasi.

Hasil ini sesuai dengan pernyataan Greenberg \& Baron (2000) bahwa karyawan atau anggota organisasi dengan komitmen yang tinggi akan memiliki loyalitas yang tinggi pada organisasi sehingga akan memunculkan perilaku bersedia berkorban demi kepentingan organisasi. Pada penelitian yang dilakukan oleh Dana \& Hasanbasri (2007) diperoleh hasil yang signifikan pula antara hubungan komitmen organisasi dan perilaku kewargaan organisasi dimana dijelaskan bahwa komitmen organisasi memberi pengaruh terhadap perilaku positif pada organisasi sehingga akan membuat percepatan penyelesaian konflik, interaksi internal antar anggota organisasi dan perilaku yang menjaga organisasi akan muncul. Dengan demikian dinyatakan bahwa komitmen organisasi memiliki hubungan terhadap munculnya perilaku kewargaan organisasi.

Dalam penelitian ini dilakukan pula uji korelasi parsial antara dimensi dari komitmen organisasi dan variabel perilaku kewargaan organiasasi. Nilai korelasi parsial yang diperoleh menunjukkan bahwa dimensi komitmen normatif memiliki nilai koefisien korelasi paling tinggi yaitu 0,512 dimana hal ini menunjukan bahwa komitmen normatif memiliki hubungan yang paling kuat dalam memunculkan perilaku kewargaan organisasi pada fungsionaris partai. Hal ini menunjukan bahwa fungsionaris tetap berada dalam partai karena dipengaruhi oleh kewajiban terhadap atasan, rekan kerja serta pengaruh pihak luar dimana dalam konteks penelitian ini sangat dipengaruhi oleh masyarakat dimana keberadaan masyarakat sebagai pendukung fungsionaris tersebut dalam meraih jabatan publik. Nilai korelasi parsial selanjutnya dengan nilai korelasi 0,320 adalah dimensi komitmen afektif, hal ini menujukkan bahwa keterikatan secara emosional, internalisasi nilai dan tujuan partai memiliki pengaruh terhadap munculnya perilaku kewargaan organisasi pada fungsionaris partai pada tingkat menengah diantara ketiga dimensi yang ada pada variabel komitmen organisasi. Dimensi terakhir yang memiliki korelasi terhadap perilaku kewargaan organnisasi yaitu komitmen continuance dengan nilai korelasi parsial 0,269 dimana menunjukan bahwa perhitungan untung rugi, kebutuhan akan pekerjaan atau jabatan dan fasilitas organisasi memiliki hubungan yang paling minimum atau memiliki hubungan yang lemah terhadap perilaku kewargaan organisasi.

Dalam penelitian ini diketahui juga bahwa nilai koefisien determinasinya ( $\mathrm{r} 2$ ) adalah 0,280 . Nilai ini memiliki arti bahwa sumbangan variabel komitmen organisasi terhadap variabel perilaku kewargaan organisasi yaitu sebesar $28 \%$ sedangkan $72 \%$ dipengaruhi oleh faktor lain di luar variabel komitmen organisasi. Menurut asumsi peneliti, variabel lain tersebut adalah kepuasan kerja, keadilan kerja, dan iklim organisasi. Fungsionaris dengan rasa kepuasan kerja tinggi akan melakukan tugas dan kewajiban melebihi dari tanggung jawabnya secara formal (Dana \& Hasanbasri, 2007) dimana hal ini terkait langsung dengan konsep dari perilaku kewargaan organisasi. Kepuasan kerja sebagai antencendent dari perilaku kewargaan organisasi juga melihat bahwa dengan adanya kepuasan kerja maka orang dalam organisasi akan lebih mungkin dalam berprilaku saling membantu dan memberikan komentar secara positif terkait organisasi (Robbins, 2006). Perilaku kewargaan organisasi juga memasukkan persepsi keadilan baik berupa keadilan pembagian tugas dan gaji dalam organisasi sebagai salah satu variabel yang akan mempengaruhi munculnya perilaku kewargaan organisasi (Robbins, 2006). Iklim organisasi yang dipersepsikan positif oleh anggota organisasi akan membuat anggota organisasi secara sukarela memberikan kontribusi positif untuk pencapaian tujuan organisasi (Prihatsanti \& Dewi, 2010).

Pada deskripsi data penelitian tampak bahwa pada variabel komitmen organisasi memiliki rata-rata teoritis sebesar 33 dan rata-rata empiris sebesar 44.05. Hal ini menunjukkan bahwa rata-rata subjek dalam penelitian ini memiliki komitmen organisasi yang tinggi (rata-rata teoritis < rata-rata empiris). Demikian juga untuk variabel, perilaku kewargaan organisasi dimana diperoleh rata-rata teoritisnya 57 dan rata-rata empirisnya 75.22 sehingga dapat disimpulkan bahwa rata-rata subjek dalam penelitian ini memiliki perilaku kewargaan yang tinggi pula (rata-rata teoritis < rata-rata empiris). Melalui uraian hasil deskripsi data penelitian, tampak bahwa subjek dalam penelitian ini memiliki komitmen organisasi dan perilaku kewargaan organisasi yang tinggi.

Dari hasil kategorisasi skor yang diperoleh subjek pada skala komitmen organisasi diketahui ada subjek kategori sangat tinggi ada 60 orang $(61,8 \%)$, kategori tinggi ada 26 orang $(26,8 \%)$ dan kategori sedang ada $11(11,3 \%)$ sedangkan pada kategori rendah dan sangat rendah tidak terdapat subjek $(0 \%)$. Hal ini menunjukkan bahwa mayoritas fungsionaris yang ada di partai Golkar di Provinsi Bali mempunyai komitmen organisasi yang sangat tinggi. Untuk kategorisasi skor pada skala perilaku kewargaan organisasi diperoleh bahwa subjek yang termasuk dalam kategori sangat tinggi ada 61 orang $(61,8 \%)$ kategori tinggi ada 24 orang $(24,74 \%)$ dan kategori sedang ada $13(13,4 \%)$ dan tidak terdapat subjek yang masuk pada kategori kategori rendah dan sangat rendah. Hal ini menunjukkan bahwa mayoritas fungsionaris partai Golkar di Provinsi Bali memiliki perilaku kewargaan organisasi yang sangat tinggi.

Hasil diatas mendukung hasil dari uji hipotesis penelitian ini yang mengatakan bahwa bila terjadi peningkatan 
pada variabel komitmen organisasi maka akan terjadi peningkatan juga pada variabel perilaku kewargaan organisasi.

\section{Kesimpulan}

1. Dari hasil penelitian ini diperoleh hasil koefisien korelasi (r) sebesar (+) 0,529. Angka korelasi yang diperoleh menunjukkan adanya hubungan antara variabel komitmen organisasi dan variabel perilaku kewargaan organisasi pada fungsionaris partai Golkar. Angka 0,529 menunjukkan hubungan antara komitmen organisasi dan perilaku kewargaan. Tanda positif menunjukkan bahwa semakin tinggi komitmen organisasi maka akan mengakibatkan semakin tinggi pula perilaku kewargaan organisasi pada fungsionaris partai Golkar.

2. Korelasi parsial antara dimensi komitmen organisasi dan variabel perilaku kewargaan organisasi menunjukkan hasil dimensi komitmen normatif memiliki koefisien korelasi parsial paling kuat terhadap perilaku kewargaan organisasi. Nilai koefisien korelasi ini menunjukkan bahwa ikatan fungsionaris terhadap rekan kerja dalam partai, pimpinan partai dan masyarakat sebagai bagian dari partai memiliki hubungan paling kuat terhadap perilaku kewargaan organisasi pada fungsionaris partai Golkar.

3. Hasil penelitian ini juga menunjukkan fungsionaris partai Golkar memiliki rata-rata komitmen organisasi dan perilaku kewargaan organisasi yang tinggi dengan hasil kategorisasi komitmen organisasi dan perilaku kewargaan organisasi yang menunjukan bahwa mayoritas dari fungsionaris partai Golkar di Provinsi Bali memiliki tingkat komitmen organisasi dan perilaku kewargaan organisasi yang sangat tinggi.

\section{Saran}

Saran Praktis Bagi Partai Golkar di Provinsi Bali

a. Pentingnya peranan organisasi dan fungsionaris di jajaran yang lebih tinggi untuk meningkatkan komitmen organisasi pada jajaran yang berada di bawahnya dengan cara memastikan individu dalam organisasi mengetahui nilai, tujuan, dan aturan dalam organisasi serta memiliki kesempatan untuk dapat berkontribusi pada organisasi. Hal ini dapat dilakukan dengan membuat sistem komunikasi berupa sistem website dan konsolidasi berjangka antar fungsionaris di setiap jajaran sehingga fungsionaris dapat menyampaikan saran dan pendapatnya bagi kemajuan partai

b. Organisasi juga dapat membuat sistem dan aturan rekruitmen penjaringan bagi fungsionaris yang ingin memperoleh kesempatan maju di pemilu kepala daerah atau pemilu legislatif secara jelas dan rinci untuk memberikan kesempatan bagi setiap fungsionaris. Hal ini dapat dilakukan dengan pelatihan fungsionaris dan sosialisasi AD- ART secara periodik.

c. Memperkuat sistem kaderisasi dan ideologi di partai agar dapat menghindari perpindahan kader partai yang potensial. Hal ini dapat dilakukan dengan mengaktifkan kembali organisasi sayap pemuda di partai sebagai sistem kaderisasi dini.

Saran Bagi Peneliti selanjutnya

a. Saran untuk peneliti selanjutnya yang ingin meneliti tentang komitmen organisasi sebaiknya menggunakan teori tentang komitmen organisasi yang lebih baru dari yang peneliti gunakan dalam penelitian ini. Peneliti selanjutnya hendaknya cermat dalam menyusun alat ukur psikologi yang akan digunakan dalam penelitian, agar skala yang digunakan bebas dari kecenderungan subjek untuk menjawab pada kesesuaian pilihan secara sosial ( social desirability)

b. Peneliti selanjutnya harus cermat dalam penyusunan itemitem pada setiap skala agar dalam uji coba alat ukur tidak terdapat item yang sebagian besar gugur pada satu dimensi

\section{DAFTAR PUSTAKA}

Aamodt, M. G. (2010). Industrial/Organizational Psychology: An Applied Approach. Belmont: Wadsworth Cenfage Learning.

Ahmad, R. Y. (2011, april 29). Politisi kutu loncat: partai saja dikhinati apalagi rakyat. Retrieved desember 1, 2012, from detiknews.com: news.detik.com

Allen, N., \& Meyer, J. (1991). Human Resource Management Review. A Three Component Conceptualizationa of Organizational commitment, 61-89.

Arikunto, P. D. (2002). Prosedur Penelitian Suatu Pendekatan Praktek. Jakarta: Rineka Cipta.

Azwar, R. C. (2009). Politik Komunikasi Partai Golkar Di Tiga Era. Jakarta: Grasindo.

Borman, W., \& Motowidlo, S. (1993). Personal Selection in Organization. San Franscisco: Jossey-Bss.

Budiarjo, M. (2008). Dasar-dasar Ilmu Politik. Jakarta: Gramedia.

Dana, \& Hasanbasri, M. (2007). Hubungan Kepuasan Kerja dan Komitmen Organisasi dengan Organitational Citizenship Behaviour di Politeknik Kesehatan Banjarmasin. KMPK Universitas Gajah Mada, 1-15.

Detiknews. (2012, July 23). Golkar prihatin dengan fenomena politisi kutu-loncat.Detiknews. Retrieved Agustus 14, 2012, from detiknews: http://news.detik.com

Dwipayana, A. (2004). Kelas dan Kasta, Pergulatan Kelas Menengah Bali. Yogyakarta: Lapera Pustaka Utama.

Garay, H.D.V.(2006). Kinerja Extra Role dan Kebijakan Kompensasi. Sinergi Kajian Bisnis dan Manajemen, Vol.8, No. 1, 33-42 
Gatra, S. (2012, Juli Selasa). Politisi.Kutu.Loncat.Tak.Layak.Dipilih Nasional.Kompas.com. Retrieved September Jumat, 2012, from Kompas.com: http://nasional.kompas.com

Greenberg, J., \& Baron, R. (2000). Behaviour In Organizations : Understanding and managing the human side of work (7th ed.). NJ: Prentice hall.

KPU. (2009, Mei 10). Hasil Pemilu 2009. Retrieved Februari 28, 2013, from Media Center KPU: www.mediacenterkpu.go.id

Luthans, F. (2005). Perilaku Organisasi edisi 10. Yogyakarta: ANDI Yogyakarta.

Luthans, F. (2006). Perilaku Organisasi edisi 10. Yogyakarta: ANDI.

Media Indonesia. (2012, Agustus 6). Media Indonesia.com. Retrieved November 15, 2012, from Pindah Partai, Kekecewaan atas Oligarki elite: www.mediaindonesia.com

Nurvida, E., Ananta, A., \& Suryadinata, L. (2005). Emerging Democrazy in Indonesia. Singapore: Institue of Southeast Asian Studies

Oei, I. (2005). Riset Sumber Daya Manusia.Cara Praktis Mengukur Stres, Kepuasan Kerja,Komitmen,Loyalitas,Motivasi kerja dan Aspek-aspek kerja karyawan lainnya. Jakarta: PT Gramedia Pustaka Utama.

Oka, D. G. (1993). Sejarah Perjalanan Golkar di Bali. Denpasar: Sekretariat Golkar Bali.

Organ, D. (1988). Organizational Citizenship Behaviour: The Good Soldier Syndrom. Lexinton Book: Lexinton MA.

Podsakoff, P., Ahaerna, M., \& Mackenzie, S. (1997). Organitational Citizenship Behaviour and Quantity and Quality Of Work Group Performance. Journal of applied psychology , vol 2 , 262-270.

Prihatsanti, U., \& Dewi, K. S. (2010). Hubungan antara Iklim Organisasi dan Organitational Citizhensip Behaviour pada Guru SD Negeri di Kecamatan Mojolaban Sukuharjo. Jurnal Psikologi Undip vol. 7, no 1 April 2010 , 11-16.

Riduwan, \& Sunarto. (2009). Pengantar Statistika untuk Penelitian Pendidiksn Sosial,Komunikasi, Ekonomi, dan Bisnis. Bandung: ALFABETA.

Riggio, R. (2003). Introduction to Industrial Organizational Psychology. New York: Prentice Hall.

Robbins, S. (2006). Perilaku Organisasi. Jakarta: PT. Indeks.

Schultz, D., \& Schultz, S. (2006). Psychology and Work Today . New Jersey: Pearson Education Inc.

Suparsa, Y. (2012, Mei 12). Kondisi Internal dari Fungsionaris Partai Golkar. (D. A. TPPN, Interviewer)

Sloat, K. (1999). Organizational Behaviour. Does your firm inspire employee to be good citizenship? , 20.

Suparsa, Y. (2012, Mei 12). Kondisi Internal dari Fungsionaris Partai Golkar. (D. A. TPPN, Interviewer)

Sugiono. (2008). Metode Penelitian Kuantitatif, Kualitatif. Bandung ; CV Alfabet

Sukuharjo. Jurnal Psikologi Undip vol.7, No. 1 April 2010, 11-16

Sweeney, P. D., \& McFarlin, D. B. (2002). Organizational Behaviour Solution For Management. New York: John E Biernat.

Tanjung, A. (2007). The Golkar Way: survival partai golkar ditengah turbulensi politik era transisi. Jakarta: Gramedia Pustaka Utama .

Tempo. (2012, JULI 27). Tempo.com POLITIK (Jejak 4 Politikus Ganti Partai Politik). Retrieved OKTOBER 4, 2012, from Tempo.com: www.tempo.com
Teresa, N., \& Suyasa, P. Y. (2008). Komitmen Organisasi dan Organitational Citizenship Behaviour pada Karyawan Call Center PT. X. Phronesis jurnal Psikologi Industri dan Organisasi Vol 10, 154-169. 